\title{
Russian Historical Science in the New Paradigm Conditions
}

\author{
Irina Alekseevna Gataullina ${ }^{1} \&$ Olga Mikhaelovna Gilmutdinova ${ }^{1}$ \\ ${ }^{1}$ The Kazan national research university of A. N. Tupolev, Russia \\ Correspondence: Irina Alekseevna Gataullina, Republic of Tatarstan, 420111, Kazan, K. Marx St., 10, Russia
}

Received: November 2, $2014 \quad$ Accepted: December 22, $2014 \quad$ Online Published: February 25, 2015
doi:10.5539/res.v7n3p158
URL: http://dx.doi.org/10.5539/res.v7n3p158

\begin{abstract}
Based on the review of the methodological transformation in the world humanitaristics, which occurred in the last century, the paper discusses the peculiarities of the development in Russian historical science at the edge of the XX-XXI centuries. The spotlight is the actual problems of history and attempts of the Russian science to "embed" into the context of the new approaches. The paper highlights the civilizational approach and simplification of its understanding, as well as the interpretation of the complexity of "modernism" and "postmodernism" concepts in the sociocultural studies. The central problem is the problem of objectivity of historical knowledge in the glocalization stage and ways to its solution it in the context of the transition from the industrial to the postindustrial society. The scale of its value system is analyzed as a new milestone, which significantly modifies the methodological strategies of the historical science in particular, and the humanitaristics in general. Transdisciplinarity is presented as a new research base in the conditions of a changing paradigm.
\end{abstract}

Keywords: modernism, postmodernism, postpostmodernism, narrative, glocalization, transdisciplinarity, "cultural turn", world system, developmentalism, acentrism, universal humanism, moral imperative, environmental dimension, intellectual history

\section{Introduction}

The historical science has always been extremely actualized by the modernity. Being inextricably linked with the past, it is modernity defining the problematic fields, outlines the research vectors of the historical knowledge, which development is aimed at responding to the requests and needs of the time. The situation experienced today in science is unique in its manifestation. It is characterized not only by the intensive growth of actual knowledge, but the formation of a new historical consciousness based on it, just as it happened during the transition of the mankind from the "extended" Middle Ages to the Modern Times-the age when the technological civilization was born, firstly, and then spread throughout the Earth. The historical picture of the world prevailing at that time requires now a serious rethinking in terms of methodological foundations and value orientations. Without this, it is impossible to assess adequately the extent and consequences of the global geopolitical and economic changes in the last decades, which radically transformed the socio-cultural space. As astutely Karl Jaspers said in 1948, "only the history of the mankind as a whole can give the scale for understanding of what is going on now". Being the foundation of socio-cultural knowledge, history influences directly the entire industry range of the humanitaristics and defines the quality level of sciences studying the society.

In the XX century, the global humanitaristics "survived" the methodological transformation, consistently moving from modernism starting from 1920s to postmodernism in the 1960s, approaching the postmodernism at the edge of the XX-XXI centuries. The heart of this process is changing the ideas of a human about himself and about the surrounding world. Such ideas in the modernism project were based on the idea of the cognizing subject as a carrier of rationality permeating all spheres of social life, and serving as a feature of the age, along with industrialization and secularization. The belief in the cult of science and the scientific and technological progress which have been firming its positions from the XVIII century, as well as social practices, have led the mankind in the XX century to such domination over the nature and society, that there emerged a real threat of total annihilation. Ulrich Beck managed to catch and determine very accurately the status of the society in the last quarter of the XX century as a society of unprecedented risk, any actions of which, whether production, knowledge expansion, new technologies, and the growth of welfare-all of them are turned against the human and the mankind (Beck, 2000). This is the reason for the substitution of modernism, interpreted as the end station of history, with the postmodernistic views. The last reflected the advent of a new historical age with a distinct state of mind (Lyotard, 1998), capable to replace the universal totality, ideology and practice of domination with 
dialogue, discourse, and plurality.

\section{Literature Review}

The methodological problems of historical science became the topic for the studies in Russia before the Revolution (Kareyev, 1915; Lappo-Danilevskiy, 1910; Khvostov, 1913). Based on studies of recognized European scientists (Droysen, 1858; Gervinus, 1895; Langlois \& Seignobos, 1899; Seignobos, 1902) of the Russian historians in the Soviet era did not receive further development: historical materialism was approved as the only way of understanding history. After the rejection of the Marxist paradigm in connection with the collapse of the Soviet system, the researchers discovered a vast field of colossal amounts of historical knowledge problems. Russian scientists began to explore actively the theoretical framework of history (Selunskaya, 2003; Rumyantseva, 2003, 2010; Smolenskiy, 2007) and to master the new approaches to it (Repina, 1998, 2011). Particular attention is paid to the micro-history, the history of everyday life, mentality, gender, and oral history, which, like a tug of clean water, filled the history with the realistic content of humans' lives. The development of these approaches would be impossible without studying the fundamental Western studies, especially those by the French Annales School (Block, 1986; Braudel, 1988; Pro, 2000; Febvre, 1994). A huge role in understanding the historical process works belongs to the British historian, Toynbee, A. (2002) and the German philosopher-existentialist, Jaspers (1994). They brought the researchers not only to the understanding the integrity and comprehensiveness of history, but also to the determination of its non-linear temporality (Rumyantseva, 2010), to identification of the source-study phenomenological paradigm of the historical methodology (Medushevskaya, 2008), as well as to understanding of interdisciplinary communication problems and developing of intellectual history tasks (Repina, 2012). The latest trend is developing in the context of contemporary research vector in the world humantitaristics (Stortz \& Panayotidis, 2001).

\section{Materials and Methods}

The article is a review. It is written based on the use of the contrastive-comparative method, revealing the methodological orientation of scientific knowledge in the world and in Russia through the correlation of the global and the local in the history, the general and the particular, the linear and the non-linear in it. The comparative approach allows deeper presentation of the current state of Russian historical science, which in the XX century was in a modernistic capsule of the Marxist paradigm. In addition, in terms of its being displaced by the new paradigmality, it was forced to master everything created by humanitaristics for the entire preceding period. Inevitable, in the absence of empirical data, speculative approach to understanding the methodology of history is overcome by the references to the authorities, as the primary means of interpretation of a problem.

Hence following linear model was no longer meeting the criteria of scientific knowledge, insofar both Marxism and the history of the states, recreated in the strict framework of the formational theory, required reconsideration. The context of the "global" and the "local" relation allowed a look, in particular, at Russian history through the prism of such problems as, for example, asynchronous movement of society in time and space, the dynamics of historical development, the unevenness and incompleteness of the phases in history. It became clear that the history of Russia is not a self-sufficient entity, but only its part developing in the general flow of the world history and obeying its regularities. The civilizational approach, actively used in 1990s, was very fruitful and, in certain sense, solved the situation of methodological ambiguities existing in the science at the edge of the centuries. It essentially flattened the "sharp corners" of the modernist model: comparativistics elements were implemented into both scientific and educational processes. However, this method did not put the Russian historiography onto the civilizational discourse. The main result of its use can be considered "persistent attempts to ontologize the results of civilizational studies", while the "civilization is not the givenness of our experience, but not more than the epistemological construct our thinking, ...a conditional heuristic model..." (Vorobyova, 2013). Objectively, the civilizational approach not only "worked" on the reproduction of the modernist model, but also put it on standby. Thus, it is not surprising that the "modernism" and "postmodernism" treated by the West-European sociocultural thought as the historical concepts, in Russian historiography still are understood increasingly as the art history concepts, which emphatically does not comply with modern scientific knowledge requirements. The situation with glocalization and coexistence in it of multi-directional political-economic and socio-cultural trends exposed one of the key problems of knowledge-the objectivity of the historical knowledge, the solution of which, in fact, shall confirm or refute the scientific status of history.

Thus, a series of scientific sensations over the last decade has put a range of new challenges for scientists. For example, the discovery of the Denisova hominin remains (in particular, the fragment of the little finger phalanx of a girl's hand) in the Altai Mountains in 2008 by a group of Russian scientists with the lead of Derevyanko (2010) claimed a thorough revision of the modern theory of anthropogenesis as an important component of the 
synthetic concept of evolution. Mapping the "Siberian Homo" genome by the specialists of the Institute for Evolutionary Anthropology n.a. Max Plank in Leipzig in 2012 confirmed that he is one special representative of the human race who avoided the main line since before the separation between the Sapiens and the Neanderthals (Brown, 2010). It means that the migration of the ancestors of modern humans to Eurasia from Africa about 50 thousand years ago was not the dominant one and, therefore, the dominant theory of the "African outcome" is only one of the options of the evolution of hominids.

The hypothesis by the astrophysicist Chechelnitskiy (2004), according to which the Far East region is the place to look for the origins of the Atlantis, allows another look at the problem of the prehistory considering the effects of the global catastrophes that leave no evidence, but tend to occur periodically on the planet, thus casting doubts on the established knowledge in the science. The Hyperborean version of the Slavic ethnic group origin belongs to one of those exciting hypotheses shedding the light not only on the earliest period of the national history, but the source of the ancestral home of the mankind (Dyomin, 2002). However, its scientific development in the absence of written sources requires new primarily paleolinguistic methods and approaches, allowing the study of the "medium history of being" through the protolanguage and myth. As for the base of historical facts serving as the basis for the recreation of the world history canvas, it is likely that in the nearest future it will be replenished with new data making a real scientific revolution in history. Scientists suggest that modern, extremely sensitive instruments and the latest technical means in general capable of "seeing" under the earth and water will cause a "chain reaction" of discoveries of ancient cities and even civilizations, sunk into the oblivion. It means, the modern historical representations are only a part of the objective knowledge open to critical analysis and subsequent understanding.

These facts indicate the necessity in the non-linear treatment of history, which is possible based on the transdisciplinarity approach, i.e. such an approach when the scientific problem can neither be formulated nor solved within the borders of any traditional discipline. The concept of reasoning caused by the "cultural turn" in the methodology is referred as an important qualitative shift in the world historiography, once having contributed to the emerging of the "new landscape of science [in it], and a new classification of academic disciplines along with it" (Repina, 2011). However, the Russian science still sees it only as program problem. Its solution requires the appropriate conditions.

\section{Discussion}

Globalization makes the trajectory of the research vector on the study of both macro-processes (political, economic, demographic, and others), and micro-history (the history of everyday life, daily routine, mentality, feelings, motivation, and mood of a human being) as multi-leveled fields of comprehension of the history, jointly forming the reliable knowledge about it. However, in order to embed into the context of the "non-linear" methodological projections, the latter shall be the point for rethinking and even restructuring the history. In the reasonable opinion of Rumyantseva (2010), a new educational model cannot but defer with the new historical knowledge, which announced the "sentence" to the linear historical writing. However, deferring fails. "We could but failed to learn how to teach history non-linearly". Why is this happening?

We suppose that this situation of the Russian science is defined by the real political-economic and socio-cultural environment of the modern Russia, which entered the global coordinates in a state of uncompleted industrial development phase. The paradox of the current moment is that there is the situation of uncertainty, strengthening and deepening of contradictions of the postmodernism age, which leitmotif is the "forefeeling of the future shock-as if a bomb has already fallen". Modernism persists as the only possible form of existence for the Russian historiography. It appears to be the reason for the modern studies to prefer the state historical narrative, while discussions on the new textbook on the history of Russia are becoming the national problem. At that, we cannot state that the Russian historiography is reclaiming no current approaches to history. The second half of 1990-ies and 2000-s became for historians the "test of the pen" both in the field of micro-history, and the history of everyday life, mentality, oral and gender history (Smolenskiy, 2007). Moreover, emerged criticism of postmodernism as a situation of "... a complete methodological uncertainty, when the only agreement possible between historians is disagreement" (Selunskaya, 2003). But to overcome the limitations of postmodernism, really expressed both as a strengthening of the private over the common, and in bringing out the concept of "object" as a synonym for the historical reality beyond the structure of thinking, we believe that it is necessary to live through this age, that is, to move from a state of industrial stage to the post-industrial reality. Russia just joins this development stage and, therefore, development of the main directions of historical knowledge in the way of postmodernism is in genesis state. After all, the total myth of progress can be overcome only by turning centrism into acentrism, and by substituting any dominance with legitimacy, originality, and pluralism. This applies to all levels of life activity in the society, starting from the "ground up to the superstructure", where, 
rephrasing Braudel (1988), "a contemptible everyman in the pursuit of profit" becomes the central character and the Agent of history, and political competition turns into the condition for the implementation of his life strategy. The world-systematic approach by Wallerstein (1987) reflects the very stage of social development, when the world-economy, overcoming the developmentalism with its presumptuous idea of progress, actually conquers the world-empires. Then we see in its entirety the problem of the study of history as a multifactorial process in the anthropological dimension. It is the development of psychological factors shall pave the way for the Russian "cultural turn", which influences the occurrence of the "new forms of studying the "social"- perhaps less ambitious but more flexible and with considerable heuristic potential" (Repina, 2011). The last is seen in the mastery of dialogue culture, defined not only as an important feature of everyday life, but the unique ability of a Human to be engaged in dialogue with the Time.

\section{Results}

Speaking about the historical process and cultural orientation of its study, as well as the need to focus attention on the psychological factors, we shall acknowledge that the study shall have abstract nature until modernism is replaced by postmodernism, and the latter is "digested" historically. Indeed, the distinction between these ages, at a first glance, is hardly distinguishable, as both concepts are based on humanism as a sociocultural basis. However, if in the first case, it is class-specific, anthropocentric, in the second case it is anti-class-specific and universal. Everything in it is subject to the environmental dimension and follows the moral imperative-the traits that the age shall acquire first to become subsequently the subject of history. Today, the age shall be intellectual, capable of giving the "answers to specific problems and changing situations" in the historical context of existence of ideas.

\section{References}

Beck, U. (2000). Risk Society: Towards a new modernity. M.: Progress-Tradition. Retrieved November 10, 2013, from http://gkaf.narod.ru/philos/bek.html

Block, M. (1986). The Apology of History, or the Craft of the Historian. M.

Braudel, F. (1988). Material civilization, economics and capitalism of XV-XVIII centuries. M.

Brown, D. (2010). Retrieved October 25, 2014, from http://www.washingtonpost.com/wp-dyn/content/article/2010/03/24/AR2010032401926_pf.html

Chechelnitskiy, A. M. (2004). The Plato Challenge: Atlantida incognita. Retrieved October 25, 2014 from http://lib.uni-dubna.ru/search/files/ogl_viz_plat/1.pdf

Derevyanko, A. (2010). Homo altaiensis. Retrieved October 26, 2014, from http://izvestia.ru/news/360188

Droysen, J. G. (2004). Grundriss Der Historik (p. 584). [Translation from German]. SPb. (First published in 1858: Grundriss Der Historik. Jena, 1858. 27 S.).

Dyomin, V. N. (2002). Russia the Annalystic (p. 72). M.: "Veche".

Febvre, L. (1994). Fights for History.

Gervinus, G. G. (1895). Autobiography (Trans. E. M. Zimmermann).

Jaspers, K. (2013). The origin and goal of history. Retrieved from http://filosbank.narod.ru/Fails/Knigi/Htm/Yaspers.htm

Kareyev, N. I. (1913). The theory of historical knowledge. SPb.

Khvostov, M. M. (1913). Lectures on the methodology and philosophy of history. Kazan.

Langlois, Ch., \& Seignobos, Ch. (1899). Introduction to the study of history (Trans. A. Serebryakova). SPb.

Lappo-Danilevskiy, A. S. (1910, 1913). The Methodology of History in 2 parts. SPb.

Lyotard, J. F. (1998). The Postmodernism Condition. Retrieved October 26, 2014, from http://lib.ru/CULTURE/LIOTAR/liotar.txt

Medushevskaya, O. M. (2008). Theory and methodology of cognitive history. M.

Pro, A. (2000). The twelve lessons of history. M.

Repina, L. P. (2011). Historical science at the edge of the XX-XXI centuries: Social theories and historiography practice (pp. 470-550). M.: "Krug".

Repina, L. P. (2012). The ideas and people in the context of the intellectual culture history. 
Rumyantseva, M. F. (2002). The theory of history. M.

Rumyantseva, M. F. (2010). Nonlinear temporality as the problem of teaching history. In Historical education in higher education institutions (p. 40). Kazan: Kazan University.

Seignobos, C. (1902). The Historical Method as Applied to the Social Sciences (Trans. P. S. M. Kogan).

Selunskaya, N. B. (2003). The problems of historical methodology (p. 64). M.

Smolenskiy, N. I. (2007). The theory and methodology of history (p. 13). M.: Publishing Centre "Akademiya".

Stortz, P. J., \& Panayotidis, E. L. (2001). Editors Introduction. History of Intellectual Culture, 1. Retrieved October 25, 2014, from http:www.ucalgary.ca/hic

Toynbee, A. (2002). A Study of History. M.

Vorobyova, O. V. (2013). Toynbee, A. J. and modern civilization studies. In Historical past and the images of history (p. 10). Saratov.

Wallerstein, I. (1987). World-Systems Analysis. In A. Giddens, \& J. H. Turner (Eds.), Social Theory Today (pp. 309-324). Cambridge: Polity Press. Retrieved November 1, 2014, from http://www.nsu.ru/filf/rpha/papers/geoecon/waller.htm

\section{Copyrights}

Copyright for this article is retained by the author(s), with first publication rights granted to the journal.

This is an open-access article distributed under the terms and conditions of the Creative Commons Attribution license (http://creativecommons.org/licenses/by/3.0/). 